\title{
DETERMINANTS OF BANK CAPITAL STRUCTURE AND PROCYCLICALITY OF LEVERAGE: AN EMPIRICAL ANALYSIS FROM TURKEY
}

\author{
Emin AVCI ${ }^{*}$ \\ Çiydem ÇATAK ${ }^{* *}$
}

\begin{abstract}
This paper investigates the determinants of bank capital structure and procyclical behavior of leverage. A panel data analysis is developed to find out the relation between different type of leverage ratios and asset growth of banks. Furthermore, possible impacts of bank specific and macroeconomic variables on the bank capital structure are discussed. The paper concludes that Turkish banks' leverage is procyclical, which is the outcome of a positive relation between asset growth and leverage. The procyclical leverage could contribute to higher instability in the financial sector and the overall economy. Therefore, further regulations are assumed to be necessary. Size, profit, number of banks, inflation, exchange rate and gross domestic product are the factors that affect Turkish banks' capital structure.
\end{abstract}

Keywords: Bank Capital Structure, Leverage, Procyclicality.

\section{BANKA SERMAYE YAPISININ BELİRLEYİCİLERİ VE KALDIRAÇ DÖNGÜSELLİĞİ: TÜRKIYYE IÇİN AMPİRIKK BİR ANALİZ}

Öz

$\mathrm{Bu}$ çalışma banka sermaye yapısının belirleyicilerini ve kaldıraç oranının döngüsel davranışını incelemektedir. Farklı tipteki kaldıraç oranları ile bankaların aktif büyümesi arasındaki ilişkiyi bulmak için bir panel veri analizi geliştirilmiştir. Ayrıca, bankaya özgü faktörlerin ve makroekonomik değişkenlerin banka sermaye yapısına olası etkileri de tartışılmaktadır. Çalışma, aktif büyüme ve kaldıraç oranı arasındaki pozitif ilişkinin bir sonucu olarak Türk bankalarının kaldıraçlarının döngüsel olduğu sonucuna varmıştır. Döngüsel kaldıraç, finansal sektör ve genel ekonomide istikrarsızlığa katkıda bulunabilir. Bu nedenle, daha fazla düzenlemenin gerekli olduğu varsayılmaktadır. Türk bankalarının sermaye yapısını etkileyen faktörler, büyüklük, kâr, banka sayısı, enflasyon, döviz kuru ve gayri safi yurtiçi hâsıladır.

Anahtar Kelimeler: Banka Sermaye Yapısı, Kaldıraç, Döngüsellik.

\footnotetext{
Assoc. Prof. Dr., Marmara University, eavci@marmara.edu.tr

** PhD Candidate, Marmara University, ciydemcatak@hotmail.com
} 


\section{Introduction}

Banks are the most important intermediaries of the financial system and occupy an outstanding position due to their functions within the national economy. Until the 2007 financial crisis, financial market regulation was based on the notion that stability of the financial system can be ensured through measures that provide solvency of each individual bank. However, the importance of systemic risks has been underestimated. In contrast to specific risks, which only affect individual financial market participants, systemic risks affect the functioning of the financial system as a whole. Risks, which are not identifiable or controllable at the bank level, can be mutually reinforced by the aggregation of individual risks and cause a crisis of the system as a whole. As a result, the micro-prudential level of regulation has been supplemented by the macroprudential level, which has a primary objective of ensuring the stability of the financial system by limiting systemic risks.

The collapse of the financial system in 2007 also once more brought to light the close link between the financial sector and the real economy. Actually the financial system was always procyclical. During economic booms with high asset prices and low-interest rates, risks are often underestimated, the value of collateral is surpassed, and credit spreads are being expanded too far. Low interest rates support innovations that enable banks to further increase their debt levels, thereby increasing their return on equity. As a consequence, leverage increases throughout the system and institutions become increasingly vulnerable even to small price corrections. The necessary reduction of the excessive leverage in the recession additionally strengthens this vulnerability. It should also be noted that such basic procyclicality of the financial system has been increased even more in recent years by regulations such as the Basel II accord. The risk weight of assets introduced by Basel II are mapped by means of external or internal ratings, which are typically underestimated in long-term risks in boom phases and must be corrected downwards during downturns. As the banks' capital requirements are smaller in the upturn than in the downturn, there is initially an increased lending expansion, which is followed by a correspondingly larger contraction. Consequently, the amplitude of the overall economic cycle increases.

Another important issue is the leverage effect, which plays an important role in strengthening economic cycles. Capital procurement is difficult to attain during crisis periods and banks must either sell assets or increase equity. In most of the cases, banks choose to sell their assets and the prices of the securities are further reduced; such reduction in prices requires additional assets to be sold again until a constant leverage ratio is reached. Hence, leverage ratio often behaves procyclically, which means that the leverage ratio increases during periods of boom and conversely, it falls during recessions.

This paper explores the procyclical behavior of leverage in the Turkish banking sector and attempts to explain determinants of bank capital structure in Turkey. In the first section of this study, the general connection between the financial system and the real economy is briefly 
discussed and a theoretical framework is outlined. In the second section, particular attention is drawn to leverage, which plays a central role in the explanation of procyclical behavior of banks. Finally, after determining the behavior of leverage, we attempt to find the determinants of leverage by analyzing the relation between selected important bank specific and macroeconomic variables and Turkish banks leverage ratios.

\section{Procyclicality}

Procyclicality is a natural part of the real and financial sectors of an economy. It is well documented by many economists that the behavior of banks is procyclical (Gambera, 2000; Salas and Saurina, 2002) and this behavior threatens macroeconomic and financial stability. It is believed that macroeconomic factors are behind each financial crisis (Salas and Saurina, 2002), as financial institutions change their activities based on changing macroeconomic conditions (Athanasoglu and Daniilidis , 2011).

As defined in the 2009 annual report of Bank for International Settlement's, a procyclical financial system "refers to the notion that its dynamics and the dynamics of the real economy reinforce each other, increasing the amplitude of booms and busts and undermining stability of both the financial sector and the real economy." In other words, when the economy is doing well, there is excessive risk taking and excessive financial activity. On the other hand, when the economy gets worse, there is not enough willingness to take risks and very little financial activity. This behavior may create a situation in which economic problems cause financial problems, that then causes economic problems again, so that the whole process continues to be repeated (Hardouvelis, 2010). Due to the cyclical behavior of banking sector, banks work as amplifiers and adversely affect financial stability instead of working as a mitigation mechanism and allocating resources efficiently within the economy and provide a stable financial system. The cyclical behavior is likely to ease their lending standards when there is an economic upturn and make it difficult when the conditions become worse (Athanasoglu and Daniilidis , 2011). In periods of expansion banks underestimate risk and reduce their capital buffer and make their selection criteria less strict and this system increases the supply of credit. In the opposite case, during recessions there is a high capital buffer ratio, the selection criteria are very strict and there is a decrease in the supply of credit. Also this system increases the strength of cyclical fluctuations instead of counterbalancing them (Cesaroni , 2015).

It is also emphasized that procyclicality is a problem arising from the interaction between the cycles of economy, finance and risk taking behavior which strengthen or support each other and move in the same direction with fluctuations in asset prices (Nijathaworn, 2009). From another perspective (Borio, etl.al., 2001), the financial accelerator mechanism arises from information asymmetries between borrowers and lenders. Information asymmetries emerge in situations where (1) there is not enough economic activity and collateral values are low, or (2) economic conditions become better than before and collateral values increase. In the first case there is an 
overestimated risk and the borrowers can't get funding from banks even for profitable projects, whereas in the second case the risk is underestimated and the firms can guarantee funding very easily even for projects that may not profitable. Hence, it can be concluded that the financial system is procyclical and amplifies business cycle fluctuations.

It is also argued that procyclicality is a part of economic system but the weaknesses of financial sector may infuriate it and turn it into a threat to macroeconomic and financial stability. These sector weaknesses include ineffective risk management and governance in supervision and in terms of dependence on volatile sources of funds (Craig, et.al., 2004). Another issue worth emphasizing refers to the interaction between the banking system and financial liberalization. In their study Demirgüç-Kunt and Detragiache (1998) tried to find out the effect of financial liberalization on the probability of banking crises. According to their study, an analysis of 53 countries shows that banking crisis are more likely to occur in liberalized financial systems. With liberalized financial systems foreign banks begin to affect domestic banks and influence the cycle with different response (Craig, et.al., 2004). While the availability of market liberalization and financial innovation allows for new opportunities, it also causes new problems. The first problem refers to the above-mentioned phenomenon that risk is typically underestimated during booms, with less regard to the potential problems it can cause, and overestimated during busts with hypersensitivity towards risk. The second problem is related to regulatory authorities that can make the cyclical behavior of banks worse with the hypothesis "too much too late". That means, the slowly developed regulatory solutions to economic and financial problems have always been a potential danger (Lowe and Stevens, 2006). From macroeconomic perspective and that bank capital regulation can cause "procyclicality", meaning that bank capital regulations can increase the effects or strength of macroeconomic fluctuations (Covas and Fujita, 2010). The cyclical behavior of banks was realized with the first Basel accord which imposed specific standards on banks like holding a constant fraction of equity. In addition, there has been an increased interest in the procyclicality issue with the Basel II accord which included risk-sensitive regulation.

Procyclicality is also clarified as a result of the adoption of risk-sensitive bank capital requirements which affect bank lending volume and exacerbate the change in business cycle. It may be due to systematic risk that arise from macroeconomic factors or from the interdependencies of financial markets and international institutions. Economic conditions are anticipated as favorable when an economy is expanding and are not favorable when an economy is contracting. Also it is known that ex-post realizations of credit problems show procyclical markings and they would increase in times of recessions and decrease during expansion. But these markings may be consistent with fixed portfolio loss distributions which have no systematic risk factors in either the failure probabilities or the loss given default (Allen, et.al., 2004).

The term "procyclicality" has been described by Kaminsky, et.al. (2004) with the adage "When it rains, it pours". They argue that macroeconomic policies are highly procyclical, especially during times of high risk and so are more dangerous than during ordinary times of the economy. In an emerging economy such as Turkey, fiscal authorities typically reduce budgets deficits while the 
central bank moves interest rates to a higher level and this probably make the bad situation worse. However, cyclical policies do not exist only in the crisis periods in many emerging economies. Some of the most basic features of debt crises in emerging economies include high spending and borrowing during the periods when the economy is expanding and international capital is abundant. In connection with this determination of appropriate capital has been discussed for many years and capital adequacy requirements have been found to be the most effective instrument to protect financial institutions from risks. Basel II accord includes many aspects to bring capital charges into use for individual loans that are decided upon by model based estimates from banks internal risk models. But the way in which capital charges and asset risk are related to each other may exacerbate procyclicality. In case that asset risks are determined by looking at economic conditions, there will be a rise in the amount of capital requirement during a downturn and bank capital is likely to be gradually destroyed by loan write offs. Banks that have limited capital cannot raise new equity easily during downturn and this situation will make the banks move into deleveraging by decreasing lending, and that makes the conditions worse (Haselmann and Wachtel , 2016).

\section{Leverage}

The relationship between leverage and economic conditions has been examined by many economists in the international arena with different approaches and methods. However, the literature related to cyclical leverage practices in Turkey received little attention. One prominent study conducted by Binici and Köksal (2012) that investigates the connection between the leverage of Turkish banks and asset growth for the period December 2002 and August 2011 and argues that banks provide money for their activities by means of equity and debt, and if leverage is the ratio of assets to equity, then any modification in the value of assets will affect the value of equity and hence there will be a change in leverage. For an economic agent, when the amount of debt remains constant, a rise in amount of asset prices would decrease leverage, which is accepted as countercyclical leverage; this situation however is different for banks. Financial institutions, which have a target leverage level, use active leverage policy, where their leverage ratio changes according to the change of the market value of assets and equity. The positive relationship between asset growth and leverage obtained from the study shows that leverage rises when there is active growth, which is evidence for the existence of procyclicality. In another study, Çalışkan (2012) utilizes bank-level panel regressions to investigate how the Turkish financial system was relatively unaffected by the global financial crisis in comparison with the US financial system with respect to bank's historical leverage ratios both on an annual and quarterly basis that covers the 1994-2009 period. As a result, the leverage of Turkish banks is found to be procyclical; it increases (decreases) when there is a growth (decline) in balance sheets. The implication is that the regulatory and supervisory reforms that were implemented in Turkey after the 2001 financial crisis helped Turkish banks to avoid large leverage growth during the US financial crisis. 
Kalemli-Ozcan, et.al. (2012) argue for the existence of leverage procyclicality for large commercial banks located in the United States but to a smaller degree in comparison to European banks. Because increasing leverage before the crisis period gave commercial banks an advantage with regard to raising funds in short term and to using off-balance sheet items to avoid capital requirements, they took excessive risk in reliance on explicit deposit insurance and implicit insurance which require earnest legal regulation. Laux and Rauter (2017) also share the same view in that understanding the determinants of procyclical leverage is crucial for recognition of possible problems which arise from reporting, regulation and management. As part of their study, they focus on the determinants of leverage procyclicality for US commercial and savings banks and blame the difference between regulatory risk weights and changes in average risk weights during the banks increase or decrease their total assets for causing procyclicality. Despite controlling various economic and bank specific variables, they discover that banks' leverage is strongly procyclical, not only because of the fair value accounting but also because of the adjustment of balance sheet. Some of the determinants that are key drivers of procyclicality are listed by the same authors as GDP growth, gains on loan sales and average risk weights.

According to the report prepared by the Basel Committee on Banking Supervision (84th Annual Report, 2014), excess leverage, which is defined as the extent to which a business funds its assets with borrowings instead of equity, can cause problems. These problems can mainly arise from fixed obligations which may not be fulfilled during economic recessions because the generated cash flow by a firm's asset level may be very low during these times. The leverage ratio in the banking sector is typically higher than in other sectors and this high level of leverage can pose a risk to the entire economic system, potentially affecting the welfare and steadiness of economy. Determining the optimal level of leverage helps to control the leverage risk which can be maintained with risk based capital adequacy ratios that ascertain the degree of banks' capital relative to the risk of its business activities. As we will also argue later, we can summarize the basic rule as "the more risk, the more capital required to balance it". Hardouvelis (2010) argue that we need to know very well what causes procyclicality for taking measures against it. He classifies the reasons into five categories. The first category is factors that are around the economic environment like globalization, technological improvements, short termism - which is the behavior of firms' managers who are not forward-looking - and inertia in household and business sentiment. The second category includes the factors related to the financial environment such as the similarity of techniques and data, determinants of risk management, similarity in the behaviors of fund managers and the behavior of rating agencies. Thirdly, factors related to economic policy makers are listed. Political pressure, the behavior of policy makers, and bias of policy makers are the cause of financial system cyclicality. In fourth place there are the factors related to the nature of the financial system, i.e. the Basel II accord and capital adequacy, bank provisioning, mark to market accounting, leverage, liquidity, collateral requirements and margin requirement, interconnectedness, home vs. host country regulations, and market structure and organization. The final category includes the design of regulatory instruments that may prevent procyclicality in financial system. These are the set of instruments such as regulatory policies, 
comprehensive regulations, countercyclical and trigger mechanisms, choice of regulators, timing, and cost of regulation. Leverage that is classified in the fourth category is blamed to cause procyclical financial system because of not being simple, and transparent and can be manipulated and circumvented easily.

Several important implications of the Baglioni et. al.s (2013) study are worth emphasizing. By analyzing a sample of 77 banks from 18 European countries, they try to find out whether there is a procyclical behavior in the banks of Eastern, Western and Atlantic countries. According to their results most of the European investment banks have procyclical leverage and this cyclicality has negative consequence on the economy and on the stability of financial system. This unpleasant situation can be prevented by relying on monetary policy with prudential measures such as regulatory limits to the leverage ratio.

The overall interaction among leverage and procyclicality with a perspective of bank leverage increases the financial system cyclicality. As can be seen by the literature provided above, bank leverage typically rises during boom periods and falls during busts, so it can be said that leverage is procyclical. The expansion and contraction of balance sheet increase the volume of cyclicality. Therefore, banks should pay attention to their borrowing and lending attitudes. To decrease procyclicality, they should limit the increase in their leverage which could be particularly provided with a long-term target level, by setting a floor on the leverage ratio during economic growth. Alternatively, there could be an established process by which during downturns the limit is relaxed because the constant leverage ratio could amplify procyclicality by making deleverage during a downturn more likely to exist (D’Hulster, 2009).

\section{Capital Structure}

A key research subject of modern corporate finance is the choice of the optimal capital structure of financial and non-financial institutions. The main matter is whether and how financing decisions affect the cost of capital and the market value of a company. The choice of the optimal capital structure also has immense importance for financial management. The starting point is the question of whether for a given capital volume capital costs are reduced in response to a change in the level of debt or an exchange of the financing instruments on the liabilities side, thereby increasing the market value of the companies.

There are different theories explaining the decisions of institutions on financial structure. The oldest theory is the irrelevance theorem which is one of the most important model and for today still serves as the basis of modern capital market theory. The irrelevance theorem goes back to the two economists Modigliani and Miller assume a perfect capital market. They state that capital structure decisions have no effect on the market value of a company. Additionally, the proportion of a company's equity and borrowed capital is irrelevant to the asset position of the shareholders. The irrelevance theorem was theoretically proved by Modigliani and Miller using the arbitrage theory, which is the possibility of making (riskless) profits by taking advantage of price differences. 
Because it is based on very rigid conditions such as the absence of insolvency costs or financerelated taxes, the theory is based on strongly simplifying assumptions and therefore has little relevance in direct practical implementation. Nevertheless, the irrelevance theorem is used as a starting point for further investigations.

Like Modigliani and Miller's Irrelevance Theory, the Trade-Off Theory also states that in complete and perfect capital markets, the market value of firm's is independent of its capital structure. Furthermore, it says that the taxation of corporate gains and the presence of bankruptcy penalties have an effect of leverage on the firm's market value. Kraus and Litzenberger (1973) introduce Static Trade-Off Theory which shows the market value of a levered firm is equal to the unlevered market value, added the corporate tax rate times the market value of the firm's debt, and subtracted the complement of the corporate tax rate times the present value of bankruptcy costs. Lastly, the model assumes that if the firm's debt obligation is more than its earnings, at that time the firm's market value is not certainly a concave function of its debt obligation.

Another theory worth emphasizing refers to the determinants of capital structure is the Pecking Order Theory. This theory concentrates on the information asymmetry between management and the investor. Managers, of course, know more than investors about the real position of the company. This leads managers to act as insiders in obtaining additional funds. Therefore, the assumptions are based on the fact that management chooses the form of financing in the interests of the company and the existing shareholders. However, the asymmetry of information influences the choice between internal and external financing. The preference of the chosen type of financing is also derived from the size and profitability of a company. This simplest form of pecking order model indicates that if the internal cash flows are insufficient for the firms' future investments and dividend commitments, then the firm issues debt. Equity is the last resort and could be used just when financial distress is very heavy.

Another pioneering theory that investigates determinants of capital structure is the Agency Theory. Jensen and Meckling (1976) define the agency relationship as: "a contract under which one or more persons (the principal(s)) engage another person (the agent) to perform some service on their behalf which involves delegating some decision making authority to the agent." When both sides of this relationship try to maximize their own utility, then it is assumed that the agent will not always act in the interests of the principal. Appropriate incentives and monitoring costs can help the principal limit this incorrect behavior of the agent. As emphasized by Harris and Raviv (1991), the conflict between debt holders and equity holders appears since the debt contract encourages equity holders to invest inappropriately. In other words, the debt contract makes it available that if an investment produces large returns, which is above the face value of the debt, then equity holders get most of the gain. But, if the investment does not succeed, because of inadequate liability, then debt holders carry on the consequences. Hereby, equity holders may invest in very risky projects, without considering that risky projects may decrease the overall value. This kind of investments follows a decrease in the value of the debt. Additionally, companies get advantage from indebtedness until the point on the increase of its value owed to the financed 
investments will be equal to the marginal costs created by the indebtedness. Consequently, the optimal quantity of indebtedness is the amount that makes the minimization of overall agency costs possible, which are the costs related to indebtedness and to appealing to externally owned funds. Grigore and Duicu (2013) emphasize that identifying the optimal capital structure doesn't mean just the arrangement of debts and equity but also specifying the part of equity owned by managers and the part of equity owned by other shareholders.

Table I: Predicted Effects Of Explanatory Variables On Leverage

\begin{tabular}{|c|c|c|c|c|c|}
\hline Variable & Studies on banks & $\begin{array}{c}\text { M\&M } \\
\text { Theorem }\end{array}$ & $\begin{array}{l}\text { Agency } \\
\text { Theory }\end{array}$ & $\begin{array}{c}\text { Trade-off } \\
\text { Theory }\end{array}$ & $\begin{array}{c}\text { Pecking Order } \\
\text { Theory }\end{array}$ \\
\hline Size & + & & + & + & - \\
\hline Collateral & -/not significant & & + & + & \\
\hline Profit & - & + & & + & - \\
\hline CPI & + & & & & + \\
\hline GDP & $+/$-/not significant & & & - & + \\
\hline M2 & - & & & & \\
\hline Exchange Rate & + & & & & \\
\hline Number of Banks & + & & + & + & \\
\hline
\end{tabular}

All of these different theories have been developed to explain the capital structure decisions and many empirical studies have been implemented to test these theories. In this study we try to explain how the debt ratio is correlated with bank-idiosyncratic and macroeconomic variables with the help of these theories. Table 1 below contains the expected effects of explanatory variables of this study, size, collateral, profit, inflation, gross domestic product, money supply, exchange rate and number of banks on leverage according to capital structure theories.

\section{Data and Methodology}

The data used in the empirical part of the study covers the period between January 2005 and December 2014. The databases of the Banking Regulation and Supervision Agency (BDDK) and Central Bank of Turkey are used for identifying the dependent, independent and control variables of the models. The sample is comprised of all of the commercial, participation, development-investment banks and banking sector information during the ten year, one 120 months observation period.

In order to explore the relationship between leverage growth and asset growth, the following basic panel model is developed:

$$
\text { Leverage Growth }_{i, t}=\beta_{0}+\beta_{1} A G_{i, t}+\beta_{2} \text { Size }_{i, t}+\beta_{3} C P I_{t}+\varepsilon_{i, t}
$$


where; Leverage growth is the growth rate of leverage ratio of banking group $i$ in period (period is determined as monthly); AG is the growth rate of the value of total assets of banking group i in period $t$ (period is determined as monthly); Size is natural log of total assets of banking group i in period $t$ (the size of balance sheet); CPI is the rate of consumer price index inflation in period $\mathrm{t}$; $\mathrm{E} i, \mathrm{t}$ is error term in year $\mathrm{t}$ for banking group $\mathrm{i}$.

In this study asset growth is used as a proxy for economic conditions. Change in asset value is considered as an indicator of the economic situation. It is generally accepted in the literature that when the asset value of a bank gets larger than there is an economic boom; and when the asset value of a bank gets smaller there is an economic bust. Parallel to the increase in asset prices, banks take more short term debt to achieve a constant target leverage ratio. With this short-term debt banks purchase longer term securities that bring higher returns than the debt they borrowed from others. When all the banks demand more assets in the market then this increases asset prices and makes economic conditions relatively better. In the opposite situation, when asset prices decrease, which is referred to as deflation, then the banks sell their assets and repay their debt to achieve the constant target leverage ratio and this has an adverse effect on the economy (Çalışkan, 2012).

While asset growth is the only explanatory variable, firm size and inflation are two control variables used in analyses. On the other hand, in the literature, different types of definitions exist for leverage ratios. Table 2 presents eight different leverage calculations, which are used as dependent variables. Hence, as eight different leverage ratios are used as dependent variables; eight different models with one explanatory and two control variables are established.

Table 2: Leverage Ratios

\begin{tabular}{ll}
\hline Leverage-1 & Total Assets / Total Equity \\
Leverage-2 & Total Debt / Total Equity \\
Leverage-3 & (Total Debt +Off Balance Sheet Liabilities) / Total Equity \\
Leverage-4 & (Tier 1 Capital-Regulatory Deductions) /(Total Assets +Off Balance Sheet Liabilities) \\
Leverage-5 & (Tier 1 Capital-Regulatory Deductions) / (Total Debt + Off Balance Sheet Liabilities) \\
Leverage-6 & Tier 1 Capital / Adjusted Assets \\
Leverage-7 & 1- (Total Equity / Total Assets ) \\
Leverage-8 & VaR / Total Equity \\
\hline
\end{tabular}

Source: Leverage 3-4 and 5 are taken from the study of Binici and Köksal (2012)

The null and alternative hypotheses are the same for all eight models and they were established as follows. The results are evaluated according to these hypotheses. Null hypothesis says that the change in asset growth doesn't have any effect on leverage ratio and alternative hypothesis states that asset growth has a significant influence on bank leverage.

$\mathrm{H} 0$ : The independent variables have no explanatory power on bank leverage $(\beta \mathrm{i}=0)$

$\mathrm{H} 1$ : The independent variables have significant explanatory power on bank leverage $(\beta \mathrm{i} \neq 0)$ 
In the second part of analysis, the determinant of bank capital structure is examined. The study employs a cross sectional regression to analyze the relationship between the leverage ratio and bank specific and macroeconomic variables. The dependent variable of this study is selected to be total assets to total liabilities labeled as leverage 1 . Three ratios have been used in the regression as a proxy for bank specific variables in the line with previous studies. These are size, collateral and profit. On the other hand, inflation, gross domestic product, money supply, exchange rate and number of banks have been chosen as macroeconomic variables.

\section{Empirical Findings}

The empirical part of the study employs panel data analysis on a dataset of commercial, participation and development and investment banks during the ten-year period between 2005 and 2014 (including 2014). Eight different models are constructed with each utilizing a different leverage ratio as dependent variable. Asset growth is used as independent variable and size and inflation are chosen as control variables. Results presented in Table 3 demonstrate that the relationship between asset growth and the leverage has an important effect on Turkish banking sector. The findings of the eight models are confirmatory with our expectations in that the selected variables quantifying leverage ratios are found to be significantly related with our asset growth proxy. In other words, higher asset growth creates considerably higher leverage in Turkey, which stands for higher indebtedness during economic booms. Conversely the leverage ratios are also falling when there is a general slowdown in economic activity.

Table 3: The Relationship between Leverage Growth and Asset Growth

\begin{tabular}{|c|c|c|c|c|c|c|c|c|}
\hline & Leverage-1 & Leverage-2 & Leverage-3 & Leverage- 4 & Leverage-5 & Leverage-6 & Leverage-7 & Leverage- 8 \\
\hline Asset Growth & $\begin{array}{l}.9613026^{* * *} \\
(.0533606)\end{array}$ & $\begin{array}{l}1.308557^{* * *} \\
(.0688255)\end{array}$ & $\begin{array}{l}.9461072^{\star * *} \\
(.2151467)\end{array}$ & $\begin{array}{l}-.6702806^{* * *} \\
(.1399375)\end{array}$ & $\begin{array}{l}-.6997298^{* * *} \\
(.1405504)\end{array}$ & $\begin{array}{l}-.8326635^{\star \star \star} \\
(.0485732)\end{array}$ & $\begin{array}{l}.3510448^{* * *} \\
(.023803)\end{array}$ & $\begin{array}{l}1.919734^{* * *} \\
(.5390692)\end{array}$ \\
\hline Size & $\begin{array}{l}.0032153^{*} \\
(.0017725)\end{array}$ & $\begin{array}{l}.0034161^{*} \\
(.0022862)\end{array}$ & $\begin{array}{l}.0020088 \\
(.0071466)\end{array}$ & $\begin{array}{l}-.0031138 \\
(.0046483)\end{array}$ & $\begin{array}{l}-.0177771 \\
(.0487312)\end{array}$ & $\begin{array}{l}-.0586086^{* * *} \\
(.0168411)\end{array}$ & $\begin{array}{l}.0092918 \\
(.0082529)\end{array}$ & $\begin{array}{l}-.0066218 \\
(.0179064)\end{array}$ \\
\hline CPI & $\begin{array}{l}.0000778^{\star \star} \\
(.0000325)\end{array}$ & $\begin{array}{l}.0001082^{* * *} \\
(.0000419)\end{array}$ & $\begin{array}{l}-.0000262 \\
(.0001311)\end{array}$ & $\begin{array}{l}.0000346 \\
(.0000852)\end{array}$ & $\begin{array}{l}.0001358 \\
(.0003483)\end{array}$ & $\begin{array}{l}.0003018^{* *} \\
(.0001204)\end{array}$ & $\begin{array}{l}-.0000293 \\
(.000059)\end{array}$ & $\begin{array}{l}.0000748 \\
(.0003284)\end{array}$ \\
\hline Constant & $\begin{array}{l}-.044636^{* * *} \\
(.0087122)\end{array}$ & $\begin{array}{l}-.0560522^{\star * *} \\
(.0112372)\end{array}$ & $\begin{array}{l}-.0152221 \\
(.0351272)\end{array}$ & $\begin{array}{l}.0208326 \\
(.0228477)\end{array}$ & $\begin{array}{l}.0762647 \\
(.1823522)\end{array}$ & $\begin{array}{l}.2511116^{* * *} \\
(.0630196)\end{array}$ & $\begin{array}{l}-.0463223 \\
(.0308824)\end{array}$ & $\begin{array}{l}.0006356 \\
(.0880144)\end{array}$ \\
\hline $\mathrm{N}$ & 360 & 360 & 360 & 360 & 360 & 360 & 360 & 360 \\
\hline R-squared & 0.4812 & 0.5077 & 0.0519 & 0.0611 & 0.0447 & 0.0829 & 0.2224 & 0.0357 \\
\hline $\begin{array}{l}\text { Prob>chi2 } \\
\text { (Hausman Test) }\end{array}$ & 0.1144 & 0.2755 & 0.4674 & 0.0658 & 0.0094 & 0.0475 & 0.0004 & 0.2879 \\
\hline Fixed Effect & No & No & No & No & Yes & Yes & Yes & No \\
\hline
\end{tabular}

Notes: ${ }^{\star * \star},{ }^{\star *}$, and ${ }^{\star}$ indicates statistically significant levels of $1 \%, 5 \%$ and $10 \%$ 
Table 4: The Relationship between Leverage and Asset Growth considering Banking Groups

\begin{tabular}{lllllllll}
\hline & Leverage-1 & Leverage- 2 & Leverage-3 & Leverage-4 & Leverage- 5 & Leverage-6 & Leverage-7 & Leverage-8 \\
\hline Asset Growth & $.9771476^{* * *}$ & $1.334424^{* * *}$ & $.9597733^{* * *}$ & $-.6997298^{* * *}$ & $-.8416893^{* * *}$ & $-.8326635^{* * *}$ & $.3510448^{* * *}$ & $1.826393^{* * *}$ \\
& $(.0521068)$ & $(.0668783)$ & $(.216828)$ & $(.1405504)$ & $(.1536633)$ & $(.0485732)$ & $(.023803)$ & $(.5426845)$ \\
Size & $.0592566^{* * *}$ & $.0691332^{* * *}$ & .0684439 & -.0177771 & -.0212961 & $-.0586086^{* * *}$ & .0092918 & .184396 \\
& $(.0180663)$ & $(.0231878)$ & $(.0751779)$ & $(.0487312)$ & $(.0532776)$ & $(.0168411)$ & $(.0082529)$ & $(.1881578)$ \\
CPI & $.0003117^{* *}$ & $.0003484^{* *}$ & -.0004881 & .0001358 & .0001565 & $.0003018^{* *}$ & -.0000293 & .0012575 \\
& $(.0001291)$ & $(.0001657)$ & $(.0005374)$ & $(.0003483)$ & $(.0003808)$ & $(.0001204)$ & $(.000059)$ & $(.0013449)$ \\
D1 & $.0724733^{* * *}$ & $.0831056^{* * *}$ & .0872354 & -.0124327 & -.0155207 & $-.0735954^{* * *}$ & .009901 & .2850526 \\
& $(.0251783)$ & $(.0323159)$ & $(.1047723)$ & $(.0679147)$ & $(.0742508)$ & $(.0234708)$ & $(.0115017)$ & $(.2622278)$ \\
D2 & $.0861648^{* * *}$ & $.1026721^{* * *}$ & .1010002 & -.0282076 & -.0341794 & $-.0862645 * * *$ & .0152945 & .2607196 \\
& $(.0260578)$ & $(.0334448)$ & $(.1084323)$ & $(.0702871)$ & $(.0768446)$ & $(.0242907)$ & $(.0119035)$ & $(.2713881)$ \\
Constant & $-.3070666^{* * *}$ & $-.3638818 * * *$ & -.3262605 & .0898114 & .1088452 & $.3043982^{* * *}$ & -.0547209 & -.8920332 \\
& $(.08455)$ & $(.1085187)$ & $(.3518312)$ & $(.2280611)$ & $(.2493384)$ & $(.0788162)$ & $(.0386234)$ & $(.8805752)$ \\
N & 360 & 360 & 360 & 360 & 360 & 360 & 360 & 360 \\
R-squared & 0.5129 & 0.5411 & 0.0556 & 0.0666 & 0.0793 & 0.4740 & 0.3871 & 0.0342 \\
\hline
\end{tabular}

Notes: ${ }^{* * *},{ }^{* *}$, and ${ }^{*}$ indicates statistically significant levels of $1 \%, 5 \%$ and $10 \%$

After determining the procyclical behavior of the Turkish banking sector, we add participant and development and investment bank as dummy variables to see whether and how the results change. D1 represent participant banks and D2 development and investment banks. Table 4 below shows the outcomes of our second analysis.

The results indicate that the leverage of the participation banks and development and investment banks is procyclical. A statistically significant relation exists between Leverage I (total Assets over total equity), Leverage II (total debt over total equity), Leverage VI (tier 1 capital / adjusted assets) and asset growth for participant and development and investment banks.

Following the finding that the Turkish bank's leverage is procyclical, we tried to figure out which bank specific and macroeconomic variables affect leverage. Table 5 below provides the list of the dependent and explanatory variables together with their abbreviations and definitions. 
Table 5: Variable, Abbreviations and Definitions

\begin{tabular}{lll}
\hline Variable & Abbreviation & Definition \\
\hline Leverage & levearge1 & the ratio of total assets to total equity \\
\hline Size & size & natural logarithm of total assets \\
\hline Collateral & collateral & total of securities, T- bills, bonds, cash and due from banks over total assets \\
\hline Profit & profit & total of pre-tax profit and interest expense over total assets \\
\hline Inflation & cpi & the rate of consumer price index inflation \\
\hline GDP Growth & gdp & annual percentage change of gross domestic product \\
M-2 Growth & m2 & money supply \\
\hline Exchange Rate & exchange & real effective exchange rate \\
Number of Banks & banknumber & total number of banks \\
\hline
\end{tabular}

Table 6 shows the signs and the levels of significance of the explanatory variables' coefficients. The results of the analysis are consistent with the prediction that leverage has an interaction with size, profit, inflation, gross domestic product, exchange rate and the number of banks. The positive influence of size on leverage with a significance level $1 \%$ and a coefficient value 29.63217 indicates that leverage increases with the size of asset. That means when a firm's tangible assets are high value and when its market-to-book ratio, which is obtained by dividing the firm's stock to its assets, is lower, it is expected that this firm's leverage has a tendency to be higher. In the same direction as the studies in the literature, we couldn't find any significant relation between collateral and leverage. However, in contrast to the literature we find a positive relation between profitability and leverage. The tradeoff theory claims that the profitable firms will use more debt because of having a high tax burden and low bankruptcy risk, so there is a positive relationship between profitability and leverage (Sayılgan, et.al., 2006). On the other hand, on the ground that profitability is a success indicator and the successful companies do not need to be indebted heavily to external world, the Pecking Order Theory says a negative relation between these two important variables. They choose to provide their funding with internal sources which are gathered from their past profits rather than providing their financing needs with external sources. It is suggested that observed capital structure of firms will reflect the cumulative requirement for external financing. As also emphasized in the study of Myers and Majluf (1984), profitable firms with slow growth rates would choose retained earnings rather than external sources as their main source of financing and unprofitable firms which run in the same sector would choose external financing to fund their operations. Therefore, unprofitable firms will have higher leverage ratios compared to the profitable firms. As a bank specific variable, number of banks express the total amount of commercial, participation and development and investment banks. Since number of banks and bank size behave towards each other, it is estimated that there is a positive relation between number of banks and leverage.

Parallel to the bank specific explanatory variables, macroeconomic variables have also a statistically significant effect on leverage. The results show that leverage is positively and 
significantly affected by the consumer price index, which is consistent with previous empirical work. This means that any increase in prices of goods and services causes higher leverage ratios. The variables GDP and exchange rate have negative and significant effects on banks leverage. Although the literature presents alternative results of the relation between GDP and leverage, the Pecking Order Theory estimates a positive relation between leverage and GDP, since economic growth is related with the growth of the company and promotes new investment opportunities and financing needs. In their study Ozkan (2001) and Gropp and Heider (2007) use real GDP as a representative for economic growth and find a positive relation between leverage and GDP growth based on the reason that during the good time, the firms use debt financing to finance their expansion programs. On the other hand the Tradeoff Theory estimates a negative relation between GDP and leverage, on account of causing higher loss of value during financial distress when there is scarcity of firms' tangible assets relative to available investment opportunities in a high growth environment (Köksal and Orman, 2007). Additionally, the number of banking institutions operating in Turkey during the period 2005-2014 has a significant effect on leverage ratio. As the number of banks increases, the leverage ratio increases.

Table 6: The Relationship between Leverage and Bank specific and Macroeconomic Variables

\begin{tabular}{lll}
\hline & Asset/Equity & \\
\hline Size & $29.63217^{* * *}$ & $(1.67143)$ \\
\hline Collateral & 1.405819 & $(.9996496)$ \\
\hline profit & $2.649969^{* * *}$ & $(.7689386)$ \\
\hline cpi & $.0541939^{* * *}$ & $(.0060101)$ \\
\hline gdp & $-.0128187^{* *}$ & $(.0056817)$ \\
\hline $\mathrm{m} 2$ & -.9162719 & $(1.101601)$ \\
exchange & $-.0149552^{* * *}$ & $(.0031379)$ \\
\hline banknumber & $.1109243^{* * *}$ & $(.0369612)$ \\
\hline trend & $.2430063^{* * *}$ & $(.0129322)$ \\
constant & $-195.8966^{* * *}$ & $(12.00827)$ \\
\hline observations & 120 & \\
\hline R-squared & 0.8866 & \\
\hline
\end{tabular}

Notes: ${ }^{* * *},{ }^{* *}$, and ${ }^{\star}$ indicates statistically significant levels of $1 \%, 5 \%$ and $10 \%$

\section{Conclusion}

This study provides empirical evidence that the leverage ratio of Turkish banks behaves cyclically. Supporting previous studies, evidence is provided for the positive connection between asset growth and leverage ratio and it is shown that during the boom phase banks use more debt.

In addition, it is shown that Turkish banks' leverage is moving in the same direction with economic conditions. Different leverage definitions have been used to prove that this is not a 
coincidence. Using eight different definitions of the leverage ratio, it is shown that procyclicality is a natural part of the real and financial sectors of Turkish economy. The implication is that the financial institutions change their activities in response to the changing economic environment. This behavior may create a vicious circle and expand the cyclical fluctuations of the real economy and produce a negative feedback to the financial sector itself. Therefore, in order to eliminate this negative feedback there should be a countercyclical leverage ratio interval. In addition, size, profit, inflation, gross domestic product, exchange rate and number of banks all have a significant effect of banks' leverage. 


\section{References}

Allen, L., Delong, G., Saunders, A. (2004). Issues in the credit risk modeling of retail markets. Journal of Banking \& Finance, 28, 727-752. doi: 10.1016/j.jbankfin.2003.10.004

Athanasoglou, P.P. \& Daniilidis, I. (2011). Procyclicality in the banking industry: causes, consequences and response. Bank of Greece Working Paper, 139.

Baglioni, A., Beccalli, E. Boitani, A. \& Monticini, A. (2013). Is the leverage of European banks procyclical?. Empirical Economics, 45(3), 1251-1266. doi: 10.1007/s00181-012-0655-4

Bank for International Settlements $80^{\text {th }}$ Annual Report (2009).

Bank for International Settlements $84^{\text {th }}$ Annual Report (2014).

Behn, M., Haselmann, R. \& Wachtel, P. (2016). Procyclical capital regulation and lending. Journal of Finance, 71(2), 919-956. doi: 10.1111/jofi.12368

Binici, M. \& Köksal, B. (2012). Is the leverage of Turkish banks procyclical?", Central Bank Review, 12(2), 11-24.

Borio, C., Furfine, C., Lowe, P. (2001). Procyclicality of the financial system and financial stability: issues and policy options. Marrying The Macro- and Micro-Prudential Dimensions of Financial Stability, BIS Papers, 01, 1-57.

Cesaroni, T. (2015). Procyclicality of credit rating systems: how to manage it. Bank of Italy Working Papers, No 109.

Covas, F. \& Fujita, S. (2010). Procyclicality of capital requirements in a general equilibrium model of liquidity dependence. International Journal of Central Banking, 6(4), 137-173.

Craig, C. S., Davis, E. P., Pascual, A. G. (2004). Procyclicality of financial systems in Asia”, In Procyclicality of financial systems in Asia. (Eds.) Gerlach S. \& Gruenwald P., Springer, 55-123.

Çalışkan, A. (2012). Leverage behavior of Turkish banks: how did they escape the global crisis?. İktisat, İsletme ve Finans, 26, 75-104.

Demirgüç-Kunt, A. \& Detragiache, E. (1998). The determinants of banking crisis in developing and developed countries. IMF Staff Papers, 45(1), 81-109. doi: 10.2307/3867330.

D'hulster, K. (2009). The leverage ratio: a new binding limit on banks. World Bank Crisis Response Note, No. 11.

Gambera, M. (2000). Simple forecasts of bank loan quality in the business cycle. Emerging Issues Series / Supervision and Regulation Dept., Federal Reserve Bank of Chicago, S\&R200-3.

Grigore, M.Z. \& Duicu, V.M.Ş. (2013). Agency theory and optimal capital structure. International Conference: CKS - Challenges of The Knowledge, 862-868.

Gropp, R. \& Heider, F. (2007). The determinants of bank capital Structure". European Central Bank Working Paper, No. 1096.

Hardouvelis, G.A. (2010). Actions for a less procyclical financial system. Eurobank Research, Economy and Markets, 5(5), 1-33.

Harris, M. \& Raviv, A. (1991) The theory of capital structure. Journal of Finance, 4681), 297-355. doi: $10.2307 / 2328697$.

Jensen, M.C. \& Meckling, W. H. (1970) .Theory of the firm: managerial behavior, agency costs and ownership structure". Journal of Financial Economics, 3(4), 305- 360.

Kalemli- Ozcan, S., Sorensen, B. \& Yesiltas, S. (2012). Leverage across firms, banks, and countries. Journal of International Economics, 88(2), 284-298. doi: 10.3386/w17354 
Kaminsky, G.L. Reinhart, C.M. \& Vegh, C.A. (2004) When it rains, it pours: procyclical capital flows and macroeconomic policies. NBER Working Paper Series, WP 10780. doi: 10.3386/w10780.

Kraus, A. \& Litzenberger, R. H. (1973). A state-preference model of optimal financial leverage. Journal of Finance, 28(4), 911-922.

Köksal, B. \& Orman, C. (2014). Determinants of capital structure: evidence from a major developing economy. Central Bank of Turkey Working Paper, WP 14/26.

Laux, C. \& Rauter, T. (2017). Procyclicality of U.S. bank leverage. Journal of Accounting Research, 43-93.

Lowe, P. \& Stevens, G. (2006). Procyclical financial behavior: what can be done?. In Procyclicality of financial systems in Asia. (Eds) Gerlach S. \& Gruenwald P., Springer, 137-160.

Myers, S. C. (1984). The capital structure puzzle. Journal of Finance, 39(3), 574- 592.

Myers, S. C. \& Majluf, N. (1984). Corporate financing and investment decisions when firms have information investors do not have". NBER Working Paper Series, WP 1396.

Nijathaworn, B. (2009). Rethinking procyclicality - what is it now and what can be done?. BIS/Financial Stability Institute-Executives' Meeting of East Asia-Pacific Central Banks High Level Meeting On "Lessons Learned From The Financial Crisis- An International And Asian Perspective", Tokyo, 30 November 2009.

Ozkan, A. (2001). Determinants of capital structure and adjustment to long run target: evidence from UK company panel data", Journal of Business Finance \& Accounting, 28, 175- 198. doi: 10.1111/14685957.00370

Salas, V. \& Saurina, J. (2002). Credit risk in two institutional regimes: Spanish commercial and savings banks. Journal of Financial Services Research, 22(3), 203-224. doi: 10.1023/A:1019781109676.

Sayilgan, G., Karabacak, H. \& Küçükkocaoğlu, G. (2006). The firm-specific determinants of corporate capital structure: evidence from Turkish panel data", Investment Management and Financial Innovations, 3, 125- 137. 
